\title{
Kualitas Air dan Pertumbuhan Semai Avicennia marina (Forsk.) Vierh pada Lebar Saluran Tambak Wanamina yang Berbeda
}

\section{Water Quality and The Growth of Avicennia marina (Forsk.) Vierh Seedling on Different Wanamina embankment canal}

\author{
Nimas Ayu Suryani $^{1 *}$, Endah Dwi Hastuti ${ }^{2}$, Rini Budihastuti ${ }^{2}$ \\ ${ }^{1}$ Program Studi Biologi, Departemen Biologi, Fakultas Sains dan Matematika, Universitas Diponegoro \\ ${ }^{2}$ Departemen Biologi, Fakultas Sains dan Matematika, Universitas Diponegoro \\ Jl. Prof. Soedarto, SH, Tembalang, Semarang \\ *Email :nimasayusuryani@gmail.com
}

Diterima 30 Juli 2018 / Disetujui 28 September 2018

\begin{abstract}
ABSTRAK
Avicennia marina merupakan jenis mangrove yang sifatnya rentan terhadap perubahan lingkungan, sehingga secara langsung dapat mempengaruhi pertumbuhannya. Lebar saluran yang berbeda akan menentukan distribusi air dan nutrient sehingga dapat mempengaruhi kualitas air yang secara langsung mempengaruhi pertumbuhan vegetasi mangrove. Penelitian ini bertujuan untuk mengkaji kualitas air dan pertumbuhan semai Avicennia marina berdasarkan lebar saluran tambak yang berbeda. Metode yang digunakan dalam penelitian ini yaitu Rancangan Acak Kelompok (RAK). Analisis data yang digunakan berupa analisis varians (ANOVA) satu faktor dengan uji lanjut Duncan dan analisis deskriptif. Faktor yang digunakan yaitu lebar saluran. Saluran dengan lebar 1m, 2m, 3m dengan 6 ulangan. Hasil analisis sidik ragam terhadap kualitas air dan pertumbuhan semai Avicennia marina selama empat bulan pengamatan pada lebar saluran yang berbeda menunjukkan hasil yang tidak berbeda nyata. Berdasarkan hasil penelitian menunjukkan bahwa lebar saluran tambak yang berbeda berpengaruh terhadap kualitas lingkungan terutama suhu. Perlakuan lebar saluran tambak wanamina yang berbeda belum memberikan pengaruh yang nyata terhadap pertumbuhan diameter batang dan kelulushidupan semai Avicennia marina.
\end{abstract}

Kata kunci: Avicennia marina, Pertumbuhan semai, kualitas air

\begin{abstract}
Avicennia marina is a type of mangrove that is susceptible to environmental changes, so it can directly affect its growth. Different canal widths will determine the distribution of water and nutrients so that it can affect the water quality that directly affects the growth of mangrove vegetation. This study aims to assess the water quality and growth of Avicennia marina seedlings based on different embankment canal widths. The method used in this research is Randomized Block Design (RAK). Analysis of data used in the form of analysis of variance (ANOVA) one factor with Duncan advanced test and descriptive analysis. The factor used is canal width. Canals $1 \mathrm{~m}, 2 \mathrm{~m}, 3 \mathrm{~m}$ wide with 6 replications. The results of the analysis of variance on water quality and growth of Avicennia marina seedlings over four months of observation on different canal widths showed no significant difference. Based on the result of research indicate that different canals width influence to environmental quality especially temperature. Different treatment of wanamina embankment canal width has not had significant effect on stem diameter and life cycle of Avicennia marina seedlings growth.
\end{abstract}

Keywords: Avicennia marina, seedling growth, water quality

\section{PENDAHULUAN}

Hutan mangrove merupakan ekosistem kompleks yang memiliki flora dan fauna yang beraneka ragam yang hidup di air maupun darat.
Mangrove menurut Giesen et al, (2007) didefinisikan sebagai tipe tanaman berkayu yang hidup di lingkungan asin dan payau. Vegetasi mangrove memiliki peran penting pada ekosistem. 
Mangrove dapat menahan nutrien melalui pengikatan oleh partikel-partikel lempung dalam ekosistem mangrove (Saenger, 2002). Melimpahnya nutrien yang terkumpul di ekosistem mangrove ini dimanfaatkan oleh berbagai jenis biota sebagai tempat mencari makan (feeding ground), pemijahan (spawning ground) dan asuhan (nursery ground). Wanamina (silvofishery) merupakan pola pendekatan teknis yang terdiri atas rangkaian kegiatan terpadu antara kegiatan budidaya ikan atau udang dengan kegiatan penanaman, pemeliharaan, pengelolaan dan upaya pelestarian hutan mangrove (Fitzgerald, 2002). Budidaya tambak dengan sistem wanamina telah dikembangkan di wilayah Mangkang, Semarang selama beberapa tahun terakhir. Tidak hanya mendukung pertumbuhan vegetasi mangrove, tambak wanamina juga mendukung keberlangsungan hidup biota di tambak seperti ikan, udang, kepiting.

Jenis mangrove yang dominan ditemukan di wilayah pesisir Kecamatan Tugu, Mangkang antara lain jenis Avicennia marina yang dapat dikategorikan sebagai tanaman perintis dalam komunitas hutan mangrove (Halidah dan Kama, 2013). Avicennia marina dapat tumbuh dengan baik apabila lingkungannya memiliki salinitas sekitar $0-30 \%$ dengan batas toleransi maksimal hingga 85\%o (Robertson \& Alongi, 1992). Tambak yang digunakan dalam penelitian ini memiliki susunan seri yang berurutan dari satu plot dengan plot yang lain, sehingga memiliki aliran air satu arah. Tambak wanamina yang digunakan pada penelitian, mangrove ditanam terpisah dengan tambak dalam beberapa hamparan berselang-seling yang menjadi bagian dari saluran air inlet dan outlet tambak yang bersangkutan. Mangrove ditanam pada lebar saluran yang berbeda yaitu $1 \mathrm{~m}$, $2 \mathrm{~m}$, dan $3 \mathrm{~m}$ dengan jarak tanam masing-masing semai $1 \mathrm{~m}$. Beberapa faktor kimia dan fisika yang diamati pada penelitian ini diantaranya; suhu dan salinitas. Kualitas air yang tidak sesuai untuk pertumbuhan mangrove akan mempengaruhi pertumbuhan vegetasi mangrove serta perkembangan ikan yang dibudidayakan.

Berdasarkan latar belakang penelitian yang telah dijelaskan, maka dapat dirumuskan permasalahan dalam penelitian ini yaitu ingin mengetahui bagaimana kualitas air pada lebar saluran tambak yang berbeda terhadap pertumbuhan semai Avicennia marina. Hasil penelitian ini diharapkan dapat memberikan informasi tentang kualitas air yang baik untuk pertumbuhan semai Avicennia marina sebagai bahan pertimbangan dalam rehabilitasi lingkungan mangrove dimasa yang akan datang.

\section{METODE PENELITIAN}

Penelitian ini dilaksanakan di tambak wanamina di wilayah pesisir Desa Mangunharjo, Kelurahan Mangkang Wetan, Kecamatan Tugu, Semarang. Penelitian dilaksanakan pada bulan Maret 2015 sampai dengan bulan Juni 2015 dengan pengamatan lapangan dilakukan secara berkala dengan periode pengamatan setiap 2 minggu sekali selama 4 bulan. Pengamatan semai dilakukan dengan menggunakan jangka sorong untuk mengukur diameter batang. Pengamatan kualitas air dilakukan dengan menggunakan Water Quality Checker untuk mengukur suhu dan salinitas pada air tambak.

Pengamatan dilakukan pada lahan tambak yang memiliki susunan seri yang berurutan dari satu plot dengan plot lain, sehingga memiliki aliran air satu arah dengan luas kolam tambak $5 \mathrm{x}$ $5 \mathrm{~m}$. Saluran tambak dibuat disamping tambak. Luas saluran bervariasi yaitu $1 \mathrm{~m}, 2 \mathrm{~m}$, dan $3 \mathrm{~m}$ (dengan panjang saluran yang sama yaitu $5 \mathrm{~m}$ ). Setiap lebar saluran yang berbeda, yaitu lebar $1 \mathrm{~m}$, $2 \mathrm{~m}$, dan $3 \mathrm{~m}$, ada 6 semai yang diamati. Perhitungan data dan grafik ditentukan dari hasil perhitungan selisih $(\Delta)$ antara pertumbuhan akhir dan pertumbuhan sebelumnya atau $\Delta=t_{n}-t_{o}$.

Penelitian ini menggunakan Rancangan Acak Kelompok (RAK), yang terdiri dari 3 perlakuan lebar saluran (1m, $2 \mathrm{~m}$, dan $3 \mathrm{~m})$ dengan 6 kali ulangan. Pengaruh kualitas air pada lebar saluran tambak wanamina yang berbeda terhadap kelulushidupan semai mangrove Avicennia Marina diamati pada akhir pengamatan dan untuk mengetahui data persentase kelulushidupan semai dihitung dengan menggunakan rumus Effendi (1997), yaitu:

$$
S R=\frac{N t}{N o} x 100 \%
$$


Keterangan:

SR : Tingkat Kelulushidupan (\%)

No : Jumlah semai yang hidup pada awal pengamatan (semai)

$\mathrm{Nt}$ : Jumlah semai yang hidup pada akhir pengamatan (semai)

Analisis data statistik melibatkan uji ANOVA. Analisis statistik dengan ANOVA antara lain untuk mengetahui pengaruh lebar saluran tambak yang berbeda terhadap kualitas lingkungan air dan pertumbuhan semai A. marina. Data yang diperoleh diuji pola distribusi dan homogenitasnya terlebih dahulu, dan dilanjutkan dengan uji Analysis of Varian (ANOVA), yang dilanjutkan dengan Duncan Multi Range Test (DMRT) dengan taraf kepercayaan 95\%. Sementara analisis deskriptif dilakukan untuk memaparkan hasil penelitian yang didukung dengan referensi yang berkaitan dengan penelitian. Analisis data dengan ANOVA dilakukan dengan SPSS 19 dengan selang kepercayaan $95 \%$.

\section{HASIL DAN PEMBAHASAN}

\section{Suhu}

Hasil analisis ANOVA menunjukkan adanya beda nyata pada lebar saluran yang berbeda terhadap suhu $(\mathrm{p}<0,05)$. Berdasarkan uji lanjut, pengamatan suhu pada lebar saluran $1 \mathrm{~m}$ dan $2 \mathrm{~m}$ menunjukkan adanya perbedaan yang nyata dengan lebar saluran $3 \mathrm{~m}$ pada setiap periode. Dapat dilihat pada Tabel 1 rerata suhu pada lebar $2 \mathrm{~m}$ memiliki nilai yang paling tinggi yaitu sebesar $32.8{ }^{\circ} \mathrm{C}$ sedangkan pada lebar $1 \mathrm{~m}$ dan $3 \mathrm{~m}$ dengan nilai sebesar $32.7{ }^{\circ} \mathrm{C}$ dan $31.9{ }^{\circ} \mathrm{C}$.

Tabel 1. Rerata suhu $\left({ }^{\circ} \mathrm{c}\right)$ kualitas air pada lebar saluran yang berbeda

\begin{tabular}{cccc}
\hline & \multicolumn{3}{c}{ Lebar Saluran Tambak Wanamina } \\
\cline { 2 - 4 } & $\mathbf{1 ~} \mathbf{~ m}$ & $\mathbf{2} \mathbf{~ m}$ & $\mathbf{3} \mathbf{~ m}$ \\
\hline Suhu $\left({ }^{\mathbf{0}} \mathbf{C}\right)$ & $32,7^{\mathrm{b}} \pm 1,39$ & $32,8^{\mathrm{b}} \pm 1,51$ & $31,9^{\mathrm{a}} \pm 1,47$ \\
\hline
\end{tabular}

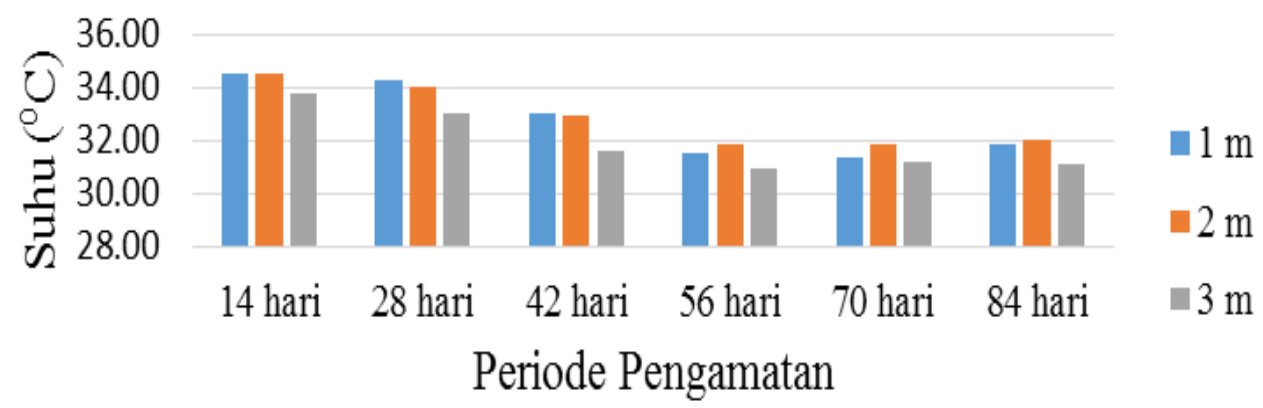

Gambar 1. grafik perubahan suhu air pada lebar saluran yang berbeda

Gambar 1 menunjukkan suhu air pada lebar $1 \mathrm{~m}$ dan $2 \mathrm{~m}$ lebih tinggi dibandingkan saluran dengan lebar $3 \mathrm{~m}$, hal ini disebabkan penetrasi cahaya pada saluran dengan lebar $1 \mathrm{~m}$ dan $2 \mathrm{~m}$ lebih banyak dan karena kurangnya naungan yang menutupi saluran dari sinar matahari. Berdasarkan grafik yang terlihat pada Gambar 1, tampak bahwa suhu air cenderung mengalami penurunan dari awal hingga akhir pengamatan pada setiap lebar saluran tambak yang berbeda. Suhu air tertinggi terdapat saluran dengan lebar $2 \mathrm{~m}$ pada periode 1 yaitu sebesar $34,55^{\circ} \mathrm{C}$ dan suhu terendah terjadi pada lebar $3 \mathrm{~m}$ di periode ke-4 yaitu sebesar $30,90^{\circ} \mathrm{C}$. Berdasarkan grafik tersebut, suhu yang terdapat pada saluran tambak wanamina merupakan suhu yang baik untuk mendukung pertumbuhan Avicenia marina. Menurut Fajar, dkk (2013), suhu yang baik untuk pertumbuhan mangrove tidak kurang dari $20{ }^{\circ} \mathrm{C}$ dan perbedaan suhu musiman tidak melebihi $5^{\circ} \mathrm{C}$.

Suhu berperan penting dalam proses fisiologis, yaitu fotosintesis dan respirasi. Berdasarkan analisis data yang telah dilakukan, suhu tidak memberikan pengaruh yang signifikan 
terhadap pertumbuhan diameter A.marina, hal ini dikarenakan berdasarkan data yang diperoleh di lapangan, suhu berkisar dari $30,90-34,55^{\circ} \mathrm{C}$. Menurut Lopez Hoffman et al, (2006) dalam Hastuti dkk (2012) menyebutkan bahwa suhu lingkungan berhubungan dengan proses fotosintesis vegetasi mangrove. Pertumbuhan A.marina terhambat pada suhu $37{ }^{\circ} \mathrm{C}$, saat suhu mengalami kenaikan, pertumbuhan A.marina melambat hingga terhenti dan tidak tumbuh lagi.

\section{Salinitas}

Data salinitas tidak dianalisis dengan uji ANOVA dikarenakan data salinitas tidak memiliki pola distribusi yang normal serta tidak seragam ( $\mathrm{p}$ $<0,05)$, sehingga tidak dapat dilakukan uji lanjut. Dapat dilihat pada Tabel 2, rerata salinitas yang paling tinggi yaitu pada lebar $1 \mathrm{~m}$ sebesar $27 \%$, sedangkan tidak berbeda jauh dengan lebar $1 \mathrm{~m}$, nilai rerata lebar $2 \mathrm{~m}$ dan $3 \mathrm{~m}$ yaitu sebesar $26.9 \%$ dan $26.2 \%$.

Tabel 2 Rerata salinitas (\%o) kualitas air pada lebar saluran yang berbeda

\begin{tabular}{|c|c|c|c|}
\hline & \multicolumn{3}{|c|}{ Lebar Saluran Tambak Wanamina } \\
\hline & $1 \mathbf{~ m}$ & $2 \mathbf{m}$ & $3 \mathbf{m}$ \\
\hline Salinitas (\%o) & 27 & 26.9 & 26.2 \\
\hline
\end{tabular}

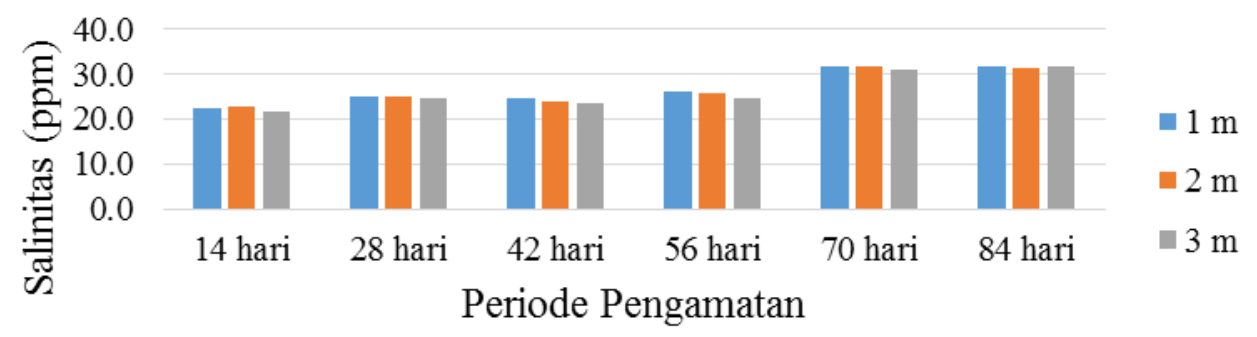

Gambar 2. Grafik perubahan salinitas air pada lebar saluran yang berbeda

Salinitas air mengalami kenaikan dari awal penelitian sampai akhir penelitian, yaitu dari musim penghujan ke musim kemarau. Menurut Hadikusumah (2008), terjadinya perubahan salinitas dalam suatu aliran disebabkan oleh adanya perubahan sirkulasi yang menyebabkan terjadinya perubahan densitas air. Gambar 2 menunjukkan bahwa salinitas air yang tertinggi terdapat pada lebar saluran tambak $3 \mathrm{~m}$ di periode ke- 6 yaitu sebesar $31,88 \%$, sedangkan salinitas terendah terdapat pada lebar saluran tambak $3 \mathrm{~m}$ di periode ke- 1 yaitu sebesar 21,6\%. Gambar grafik salinitas yang terlihat merupakan hasil yang baik untuk mendukung pertumbuhan semai A.marina yang didukung oleh pendapat Hastuti (2012) yaitu salinitas dan pertumbuhan Avicennia memiliki korelasi positif dimana peningkatan salinitas akan merangsang pertumbuhan Avicennia. Kisaran salinitas terbaik untuk pertumbuhan bibit Avicennia adalah $5-30 \%$. Berdasarkan hal tersebut, nilai salinitas pada penelitian merupakan nilai yang sesuai untuk pertumbuhan mangrove, karena nilai salinitas pada penelitian berkisar antara 21-30 \%o. Namun demikian, kadar salinitas memiliki kisaran yang tinggi pada periode-periode akhir pengamatan saat terjadinya musim kemarau (bulan Mei - Juni), sehingga pertumbuhan semai menurun. Walaupun mangrove toleran terhadap kadar salinitas yang tinggi, proses adaptasi mangrove agar dapat bertahan hidup dengan cara menyimpan $\mathrm{Na}$ dan $\mathrm{Cl}$ pada bagian kulit kayu, akar dan daun yang lebih tua. Daun yang menyimpan garam lalu menggugurkan diri untuk mengeluarkan kelebihan garam yang dapat menghambat pertumbuhan dan pembentukan buah.

Ion $\mathrm{Na}^{+}$dan $\mathrm{Cl}^{-}$pada salinitas diperlukan mangrove di dalam mengatur potensial osmotik antarsel (Onrizal, 2005). Salinitas merupakan akumulasi garam yang terkandung pada tanah dan dapat terdispersi ke dalam air dengan adanya 
pergerakan air. Kondisi hypersaline (kadar salinitas yang tinggi) dapat menghambat pencampuran nutrien pada air tambak (Wolanski, 1986 dalam Andutta et al, 2011). Mangrove pada umumnya dapat beradaptasi pada lingkungan dengan salinitas tinggi karena mangrove memiliki akar nafas yang membantu untuk mengambil oksigen di udara apabila kekurangan oksigen pada media tanamnya, lentisel untuk pertukaran karbondioksida dan oksigen dalam membantu proses pertumbuhan batang dan trikoma garam yang menyerap air pada lingkungan salinitas tinggi kemudian mengekskresikan garam dengan trikoma glandulae yang terdapat pada daun. Apabila trikoma glandulae pada permukaan bawah daun pecah, akan muncul butiran putih sepeti tepung.

\section{Diameter Batang}

Diameter batang dari semai Avicennia marina diukur pada ketinggian $30 \mathrm{~cm}$ dari pangkal akar. Pertumbuhan diameter batang merupakan pertumbuhan sekunder yang disebabkan oleh adanya jaringan kambium, yaitu jaringan yang mengakibatkan batang bertambah besar (Triharso, 2004). Pertumbuhan diameter berlangsung apabila keperluan hasil fotosintesis untuk respirasi, penggantian daun, pertumbuhan akar dan tinggi telah terpenuhi (Latifah, 2004).

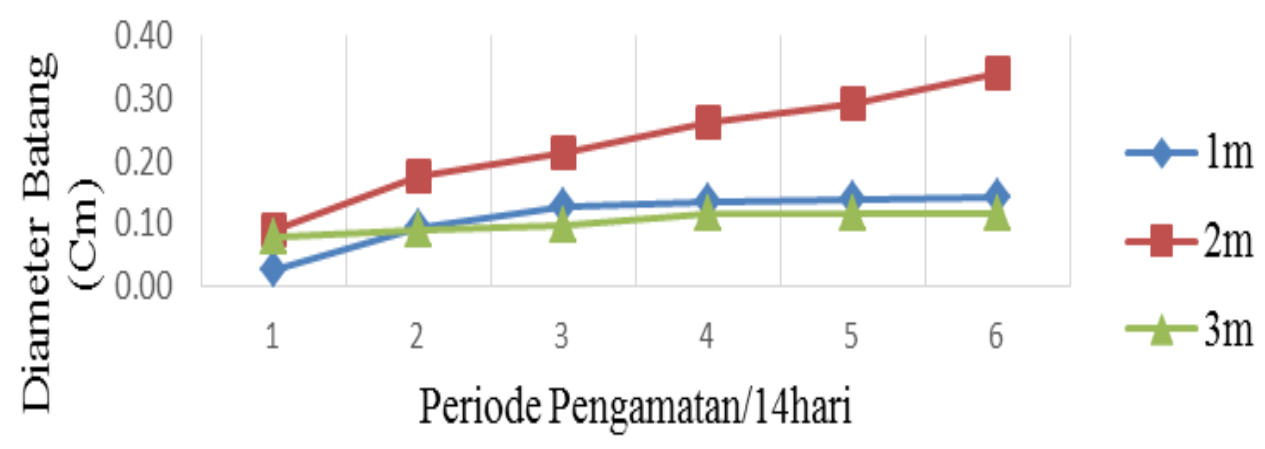

Gambar 3. Grafik pertumbuhan diameter batang semai avicennia marina pada lebar saluran yang berbeda

Gambar 3 menunjukkan adanya pengaruh lebar saluran $1 \mathrm{~m}, 2 \mathrm{~m}$, dan $3 \mathrm{~m}$ terhadap pertumbuhan diameter batang semai Avicennia marina. Lebar $1 \mathrm{~m}$ dan $2 \mathrm{~m}$ menunjukkan pertumbuhan diameter batang semai yang cukup baik dibandingkan lebar saluran $3 \mathrm{~m}$. Pertumbuhan diameter batang paling tinggi pada lebar $1 \mathrm{~m}$ terjadi pada periode 4 yaitu sebesar $0.14 \mathrm{~cm}$. Pada lebar $2 \mathrm{~m}$ pertumbuhan diameter batang yang paling tinggi terjadi pada periode 6 yaitu sebesar $0,34 \mathrm{~cm}$. Pada lebar $3 \mathrm{~m}$ pertumbuhan diameter batang yang paling tinggi terjadi pada periode 4 yaitu sebesar $0,12 \mathrm{~cm}$.

Pertumbuhan diameter semai dipengaruhi oleh aktivitas jaringan meristem yakni meristem lateral. Meristem lateral atau meristem samping adalah meristem yang menyebabkan pertumbuhan ke arah samping (membesar), terletak sejajar dengan permukaan organ. Aktivitas jaringan meristem lateral menimbulkan pertambahan diameter tumbuhan. Pertumbuhan diameter semai Avicennia marina sangat dipengaruhi oleh kondisi lingkungan yang menjadi tempat tumbuhnya. Pertumbuhan diameter berlangsung apabila keperluan hasil fotosintesis untuk respirasi, pertumbuhan akar dan tinggi telah terpenuhi (Latifah, 2004).

Pertumbuhan diameter batang sangat dipengaruhi oleh tinggi rendahnya salinitas air. Salinitas yang tinggi dapat mengganggu aktivitas dari meristem lateral. Kurniasari, dkk (2010) menyatakan bahwa gangguan pada meristem lateral terjadi akibat keterbatasan penyerapan air oleh akar yang disebabkan oleh tingginya tekanan osmotik dalam larutan tanah akibat adanya $\mathrm{NaCl}$. Diameter batang sangat dipengaruhi oleh terjadinya perkembangan sel baru, pemanjangan dan penebalan dinding sel, proses tersebut sangat 
membutuhkan karbohidrat dan absorbs air bagi pembesaran vakuola-vakuola pada semua bagian yang sedang mengalami pertumbuhan (Harjadi, 1993).

\section{Kelulushidupan Semai}

Kelulushidupan yaitu perbandingan antara jumlah individu yang hidup pada akhir percobaan dengan jumlah individu pada awal percobaan. Kelulushidupan dipengaruhi oleh faktor biotik dan abiotik. Faktor biotik seperti parasit, kompetitor, predasi, umur, kemampuan adaptasi, penanganan manusia dan kepadatan populasi, sedangkan sifat kimia dan fisika dari suatu lingkungan air merupakan faktor abiotik. (Rika, 2008).

Salah satu faktor penting yang diamati dalam penelitian ini yaitu tingkat kelulushidupan (survival rate) semai mangrove yang ditanam pada lebar saluran tambak wanamina yang berbeda. Tingkat kelulushidupan semai mengindikasikan kesesuaian kondisi lingkungan bagi kehidupan mangrove yang ditanam. Hasil pengamatan terhadap tingkat kelulushidupan semai mangrove yang ditanam pada lebar saluran tambak wanamina yang berbeda disajikan pada Tabel 3 .

Tabel 3. Tingkat Kelulushidupan (Survival Rate / SR) Semai Avicennia Marina

\begin{tabular}{cccccc}
\hline $\begin{array}{c}\text { Jenis } \\
\text { Mangrove }\end{array}$ & $\begin{array}{c}\text { Lebar } \\
\text { Saluran }\end{array}$ & $\begin{array}{c}\text { Jumlah } \\
\text { Awal } \\
\text { Semai }\end{array}$ & $\begin{array}{c}\text { Jumlah } \\
\text { Akhir } \\
\text { Semai }\end{array}$ & Keterangan & SR \\
\hline \multirow{2}{*}{ Avicennia } & $1 \mathrm{~m}$ & 6 & 1 & Hidup & $17 \%$ \\
marina & $2 \mathrm{~m}$ & 6 & 2 & Hidup & $33 \%$ \\
& $3 \mathrm{~m}$ & 6 & 0 & Mati & $0 \%$ \\
\hline
\end{tabular}

Hasil analisis terhadap tingkat kelulushidupan semai mangrove menunjukkan kisaran yang sangat rendah pada semai Avicennia marina. Tingkat kelulushidupan yang rendah tersebut diakibatkan oleh perubahan kondisi lingkungan dari musim penghujan ke musim kemarau yang menyebabkan rendahnya masukan air tawar. Menurut Hutching dan Saenger (1987) dalam Kusmana (2000) kisaran temperatur optimum untuk pertumbuhan Avicennia marina pada temperatur $18^{\circ}-20 \quad{ }^{\circ} \mathrm{C}$ sedangkan pada pengamatan berlangsung, temperatur melebihi batas optimum untuk pertumbuhan semai Avicennia marina yaitu $31^{\circ}-34^{\circ} \mathrm{C}$.

Tingkat kelulushidupan semai pada saluran dengan lebar $2 \mathrm{~m}$ lebih tinggi yaitu sebesar $33 \%$ dibandingkan lebar $1 \mathrm{~m}$ dan $3 \mathrm{~m}$ yaitu sebesar $17 \%$ dan $0 \%$. Hal ini dapat disebabkan pada lebar $2 \mathrm{~m}$ mangrove mendapatkan ruang yang cukup untuk tumbuh serta suplai nutrient yang dibutuhkan untuk pertumbuhan tercukupi berbeda dengan lebar $3 \mathrm{~m}$ yang memiliki jumlah spesies lebih banyak dibandingkan lebar $2 \mathrm{~m}$ dan lebar 1 $\mathrm{m}$ yang memiliki ruang cukup kecil untuk pertumbuhan. Hal ini sesuai dengan pendapat Utina, dkk (2012) yang menyatakan bahwa semakin banyak jumlah spesies mangrove, semakin rumit pula bentuk kompetisinya. Dalam hal ini dapat berupa kompetisi dalam mendapatkan ruang untuk tumbuh, nutrient, ataupun banyak sedikitnya penetrasi cahaya yang dapat masuk kedalam perairan.

Avicennia marina banyak yang mati akibat stress karena kenaikan suhu dilokasi penelitian. Taniguchi (1999) dalam Suwigno, dkk (2009) menyebutkan bahwa dalam kondisi alami proses adaptasi sangat rendah dan persentase hidup mangrove sekitar 20\% - 30\%. Semai A.marina sebelum mengalami kematian mengalami kerontokan daun yang cukup banyak dan pucuknya mengering. Suhu yang tinggi menghalangi transport nutrient ke meristem, sehingga jaringan meristem mati dan pertumbuhan terhambat ditandai dengan rontoknya daun-daun. Suhu yang tinggi juga menyebabkan transpirasi tinggi, hal ini menyebabkan protoplasma mengalami dehidrasi akibat daun kekurangan air. Daun-daun A.marina yang rontok pada saluran tambak menyebabkan kecerahan perairan pada saluran menjadi rendah dan kekeruhan meningkat. Hal ini menyebabkan rendahnya penetrasi cahaya yang dapat masuk kedalam perairan. Odum (1971) 
dalam Raharjo (2003) menyatakan bahwa kecerahan perairan merupakan faktor fisika yang menentukan jauhnya penetrasi cahaya yang masuk kedalam perairan yang dapat mendukung proses fotosisntesis tanaman. Semakin cerah suatu perairan maka proses fotosintesis tanaman akan lebih baik, sehingga pertumbuhan tanaman akan lebih optimal, sebaliknya jika kecerahan perairan menurun radiasi sinar matahari yang dibutuhkan untuk proses fotosintesis tumbuhan akan kurang dan pertumbuhan tanaman terhambat. Hal inilah yang diduga menyebabkan pertumbuhan semai terhambat/mati pada saat penelitian sehingga tingkat kelulushidupan menjadi rendah.

\section{SIMPULAN}

Berdasarkan hasil penelitian dan pembahasan yang telah dijelaskan mengenai kualitas air dan pertumbuhan semai Avicennia marina pada lebar saluran tambak wanamina yang berbeda dapat ditarik kesimpulan sebagai bahwa lebar saluran tambak yang berbeda berpengaruh terhadap faktor lingkungan terutama parameter suhu. Perlakuan lebar saluran tambak wanamina yang berbeda tidak berpengaruh terhadap pertambahan diameter batang dan kelulushidupan semai Avicennia marina.

\section{DAFTAR PUSTAKA}

Andutta, Fernando P., Peter V. Ridd and Eric Wolanski. 2011. Dynamics of Hypersaline Coastals Waters in the Great Barrier Reef. Estuarine, Coastals and Shelf Science 94 (2011) 299-305.

Effendi, M.I. 1997. Metoda Biologi Perikanan. Yayasan Pustaka Nusantara. Yogyakarta.

Fajar, Al., Dedy Oetama., dan Alirman Afu. 2013. Studi Kesesuaian Jenis untuk Perencanaan Rehabilitasi Ekosistem Mangrove di Desa Wawatu Kecamatan Moramo Utara Kabupaten Konawe Selatan. 03(12): 164176

Fitzgerald, W. J., 2002, Silvofisheries: Integrated Mangrove Forest Aquaculture Systems, in B.A. Costa-Pierce (editor), Ecological
Aquaculture: The Evolution of a Blue Revolution. Blackwell Science Ltd, Oxford, UK.

Giesen, W., W. Stephen, Z. Max dan S. Lichsbeth. 2007. Mangrove Guides Book for Southeast Asia. FAO and Wetlands International. Dharmasam, Co. Ltd.

Hadikusumah.2008. Karakteristik parameter fisika dan kandungan klorofil-a di Laut Jawa. Jurnal Ilmu Kelautan. 13 (2): 103-112.

Halidah dan Kama, Harwiyaddin. 2013. Penyebaran Alami Avicenia marina (Forsk) Vierh dan Sonneratia alba Smith pada Substrat Pasir. Indonesian Forest Rehabilitation Journal Vol. 1 No. 1, September 2013: 51-58.

Harjadi, M.M.S.S. 1993. Pengantar Agronomi. Gramedia Pustaka Utama.

Hastuti, E. D. 2012. Interaksi Struktur Komunitas Vegetasi dengan Kualitas Lingkungan di Kawasan Sempadan Pantai SemarangDemak. Disertasi. Program Doktor Program Pascasarjana Universitas Diponegoro Semarang, Semarang.

Hastuti, E. D, Sutrisno A., dan Rudhi P. 2012. The Effect of Environmental Factors on the Dynamic Growth Pattern of Mangrove Avicennia marina. Journal of Coastal Development ISSN : 1410-5217 Volume 16, Number 1, Oktober, $2012: 57-61$

Kusmana, C. 2000. Ekologi Mangrove. Fakultas Kehutanan IPB. Bogor

Kusniari A, M, Adisyahputra dan Rosihan R. 2010. Pengaruh Kekeringan pada Tanah Bergaram $\mathrm{NaCl}$ terhadap Pertumbuhan Tanaman Nilam. Bul. Litro. Vol. 21 No.1.

Latifah, S. 2004. Pertumbuhan dan Hasil Tegakan Eucalyptus grandis di Hutan Tanaman Industri. Universitas Sumatra Utara. Medan.

Onrizal. 2005. Adaptasi Tumbuhan Mangrove pada Lingkungan Salin dan Jenuh Air. Medan: Universitas Sumatera Utara. 
Raharjo, A.M. 2003. Pengaruh Kualitas Air pada Tambak Tidak Bermangrove dan Bermangrove Terhadap Hasil Udang Alam di Desa Grinting Kabupaten Brebes. Tesis. Universitas Diponegoro. Semarang.

Rika. 2008. Pengaruh Salinitas terhadap Pertumbuhan dan kelulushidupan IkanHasil Strain GIFT dengan Strain Singapura. Skripsi, Universitas Diponegoro. Semarang.

Robertson., Alongi. 1992. Avicennia marina. http://www.iucnredlist.org. Diakses pada 2 Agustus 2015.

Saenger, P. 2002. Mangrove Ecology, Silviculture and Conservation. Kluwer Academic Publishers. Dordrecht/Boston/London.

Suwigno, R.A., Munandar dan Sarno. 2008. Konservasi Kandelia Candel Sebagai Upaya Menjaga Biodiversitas Hayati Mangrove. Departemen Biologi, FMIPA Universitas Airlangga.

Triharso. 2004. Dasar-dasar Perlindungan Tanaman. Edisi 3. Penerbit Gadjah Mada University Proses, Yogyakarta.

Utina, R., Katili, A.S., Ibrahim, M. 2012. Komposisi dan Struktur Vegetasi Tumbuhan Mangrove Asosiasi di Kawasan Pesisir Kwandang Kabupaten Gorontalo Utara dan Kawasan Pesisir Mananggu Kabupaten Boalemo. Laporan Penelitian. Unversitas Negeri Gorontalo. 